\title{
EGFR NP_005219.2:p.L747_S752del
}

National Cancer Institute

\section{Source}

National Cancer Institute. EGFR NP 005219.2:p.L747 S752del. NCI Thesaurus. Code C98559.

A deletion of six amino acids from the epidermal growth factor receptor protein from the leucine at position 747 through the serine at position 752 . 